Scientific Journal of October 6 University

ISSN (Print): 2314-8640

ISSN (Electronic): 2356-8119

Published by October 6 University @ All Rights Reserved

Available online at: http://sjou.journals.ekb.eg
Citation: Ahmed and Laila, (2018). Rutin Ameliorates AcrylamideInduced Hepatotoxicity and Biochemical Disturbance in Male Albino Rats. Sci. J. of Oct. 6 Univ. 4(2), 8-13.

Copyright: (C) 2018 Ahmed and Laila. This is an open-access article distributed under the terms of the Creative Commons Attribution License, which permits unrestricted use, distribution, and reproduction in any medium, provided the original author and source are credited.

\title{
Rutin Ameliorates Acrylamide-Induced Hepatotoxicity and Biochemical Disturbance in Male Albino Rats
}

\section{Mahgoub M Ahmed and Ibrahim M Ibrahim Laila}

\begin{abstract}
Molecular Drug Evaluation Dep. National Organization for Drug Control and Research (NODCAR), Giza,
\end{abstract} Egypt

Received: 09-07-2018/ Revised: 22-08-2018 / Accepted: 04-10-2018

\begin{abstract}
The present study investigated the effect of rutin on acrylamide (ACR) toxicity was evaluated in experimental animal rats. The rats were feeding on basal diet and received oral $20 \mathrm{mg} / \mathrm{kg} \mathrm{b} . \mathrm{w}$ of acrylamide with 100,50 and $25 \mathrm{mg} / \mathrm{kg}$ w.t of rutin; others were received the acrylamide concentrations only. The present results showed that 8-hydroxydeoxy guanidine (8-OHdG), protein carbonyl (PC), reactive oxygen species (ROS), glutathione peroxidase (GPx), tumor necrosis factor- $\alpha$ (TNF- $\alpha$ ), nitric oxide (NO) myeloperoxidase (MPO), caspase-3, bax, P53 and cytochrome-C in liver tissues were increased in rats-treated with acrylamide. This effect of acrylamide was attenuated by rutin. In conclusion, rutin ameliorates hepatotoxicity induced by acrylamide in male albino rats. It can be recommend the use of rutin to mitigate the acrylamide concentration in food products.
\end{abstract}

Key words: Acrylamide, rutin, oxidative stress

\section{Introduction}

Diabetes In 2002, high level of ACR was detected in some fried and grilled starchy foods, which may be produced by the reaction between asparagine and reducing sugars or reactive carbonyls at temperatures above $120^{\circ} \mathrm{C}$ (Mottram et al., 2002). The discovery of ACR in cooked starchy foods prompted concerns about the carcinogenicity of those foods. Genetic toxicology studies have found that ACR has mutagenic effects both in vivo and in vitro experiments, and it can cause gene mutation and chromosomal abnormalities of somatic and germ cells of mammalian, such as the formation of micronuclei, and sister chromatid conversion (Camacho et al., 2012). Moreover, it has been reported that epoxypropionamide, a metabolites of $\mathrm{ACR}$, is the main material of mutagenic activity, which is easy combined with guanine of DNA then forming an adduct. International Agency for Research on Cancer (IARC) have evaluated the carcinogenicity of AA and listed it as a category carcinogen (Forstova et al., 2014). Toxicity evaluation of pollutants is mainly carried out through the biological tests which spend a long time and high cost. What is more, it is difficult to test various amounts of contaminants in water individually. In comparison, DNA biosensors providing a cheap and fast approach for the study of toxicity of pollutants have attracted much research interest Liu et al. (2012).

Rutin (quercetin-3-rutinoside), a natural flavonoid glycoside, being already clinically used for strengthening of capillaries (Wadworth and Faulds, 1992), possesses as other flavonoids iron/copper chelating and antioxidant activity which based on the mentioned known pathological mechanism, appears to be a useful drug.

Flavonoids are a large family of over 4000 ubiquitoussecondary plant metabolites, comprising seven subclasses, anthocyanins (e.g. europinidin), flavones (e.g. apigenin), flavonols (e.g. quercetin), flavanonols (e.g. taxifolin), isoflavones (e.g. genistein), flavanones (e.g. naringenin) and flavonol glycosides (e.g. rutin). Flavonoids are known to possess strong antioxidant properties, which can be due to both their radical-scavenging effects and metalchelating properties, of which the former may dominate. Owing to the antioxidant properties, they can prevent deoxyribonucleic acid (DNA) and cells from oxidative damage, and thus possess a wide range of pharmacological 
activities such as anti-tumor, anti-inflammatory and anti-aging (Undeger et al., 2004).

Rutin ( Scheme 1 ), is one of the most abundant flavonoids in the human diet, also known as vitamin $\mathrm{P}$, has been shown to act as a scavenger of various oxidizing species, i.e. hydroxyl and peroxyl radicals. As a result of these biological effects, its pharmacological activities have been widely explored including antibacterial, anti-inflammatory, antitumor, antiallergic, antiviral and antiprotozoal properties (Blasco et al., 2004; Hasumura et al., 2004).

\section{MATERIALS AND METHODS MATERIALS \\ - Chemicals}

The chemicals used in the present study as well as their sources are displayed as follows:

rutin was obtained from Sigma Chemical Company, USA. All other chemicals used in the present investigation were of bioanalytical grade.

Experimental animals

Sixty adult male albino rats weighing between 160$180 \mathrm{~g}$ were used. The rats were obtained from the animal house of the National Organization for Drug Control and Research Egypt. The animals were kept under standard laboratory conditions of light/dark cycle $(12 / 12 \mathrm{~h})$ and temperature (20 $25^{\circ} \mathrm{C}$ ) for one week. They were provided with a nutritionally adequate basal laboratory diet. The basal diet consists of casein $10 \%$, cotton seed oil $4 \%$, salt mixture $4 \%$, vitamin mixture $1 \%$, carbohydrates (sucrose, starch 1:1) $80.8 \%$ and Choline Chloride $0.2 \%$ (American Institute of Nutrition., 1980).

Grouping of animals

A total number of 60 adult male albino rats were divided to equally sex groups as follow:

1-Normal control (NC): Rats were feeding basal diet. 2-Rats were feeding basal diet and received orally $20 \mathrm{mg} / \mathrm{kg}$ acrylamide alone.3-Rats were feeding basal diet and received orally $20 \mathrm{mg} / \mathrm{kg}$ acrylamide (ACR) and $100 \mathrm{mg} / \mathrm{kg}$ rutin (RU).4Rats were feeding basal diet and received orally $20 \mathrm{mg} / \mathrm{kg}$ acrylamide (ACR) and $50 \mathrm{mg} / \mathrm{kg}$ rutin (RU).5- Rats were feeding basal diet and received orally $20 \mathrm{mg} / \mathrm{kg}$ acrylamide (ACR) and $25 \mathrm{mg} / \mathrm{kg}$ rutin (RU). 6- Rats were feeding basal diet and received orally $100 \mathrm{mg} / \mathrm{kg}$ rutin (RU) alone.

\section{Handling of Tissue Samples}

Liver was collected and weighed. The liver was homogenized $(10 \%, w / v)$ separately in ice-cold $\mathrm{KCl}(1.15 \%)$ sodium phosphate buffer $(0.01 \mathrm{M}, \mathrm{pH}$ 7.4) with a Potter-Elvehjem glass homogenizer (EZ stir, Korea). The homogenate was centrifuged at $10,000 \times g$ for $20 \mathrm{~min}$ at $4^{\circ} \mathrm{C}$ (Sigma $3 \mathrm{k} 30$, Germany). The supernatant of the liver was divided into three aliquots and collected into sterilized Eppendorf tubes and stored at $-80^{\circ} \mathrm{C}$ until analysis. The supernatant was used for the estimation the level of NO (Wang et al., 2002) using Griess reagent, Protein Carbonyl (Levine et al., 1990) Levels of TNF- $\alpha, 8-\mathrm{OHdG}$, cytochrome-c, caspase3 , Bax, and p53 were quantified using ELISA (BioTek, ELx-50, USA) kits according to the manufacturer's instructions and guidelines. Protein content in the supernatant was estimated by the method of Lowry et al. (1951).

\section{Histological examination}

Part of the liver was placed in well-sealed containers containing $10 \%$ formalin saline solution for $10 \mathrm{~h}$ at least, and then washed in tap water for 12 h. Serial alcohols (methyl, ethyl and absolute ethyl alcohols) were used for dehydration of the tissue samples. Tissue specimens were cleared in xylene and embedded in paraffin. The paraffin blocks were sectioned at 3 micron thickness by slide microtome. The obtained tissue sections were collected on the glass slides and stained by haematoxylin and eosin stains (Banchroft et al., 1996) for histological examination by the light microscope.

\section{METHODS}

Bioassay

Determination of Myeloperoxidase (MPO) Activity: Myeloperoxidase activity was determined using Bradley et al. (1982) method.

Determination of GPx activity: The activity of GPx was determination according to BrigeliusFlohe (1999).

Quantification of reactive oxygen species (ROS) content: A modified version of a previously described assay for the intracellular conversion of nitro blue tetrazolium (NBT) to formazan by superoxide anion was used to measure the generation of reactive oxygen species (Vrablic $\boldsymbol{e t}$ al., 2001).

Determination of Nitric Oxide content: Nitric oxide (NO) level was measured by the determination of total nitrate and nitrite concentrations in the sample using the method of (Wang et al., 2002, using Griess reaction).

Determination of lipid peroxidation content: Lipid peroxides formation was determined in serum and brain homogenate as thiobarbituric acid reactive substances (TBARS). It was determined according to the method of (Uchiyama and Mihara 1978).

Determination of Protein Carbonyl Concentration:Protein carbonyl concentration was measured in liver and heart by first forming labelled protein hydrazone derivatives using 2, 4dinitrophenyl hydrazide (Smith et al., 1991).

Determination of tumor necrosis factor- $\alpha$ (TNF$\boldsymbol{\alpha})$. The activity of TNF- $\alpha$ was calculated according to (Bonavida 1991). The Rat TNF- $\alpha$ ELSA (Enzyme-Linked Immunosorbent Assay) kit is an in vitro enzyme-linked immunosorbent assay for the quantitative measurement of rat TNF- $\alpha$ in cell lysate and tissue lysate. 
Determination of 8-hydroxy-2 deoxyguanosine (8-OHdG). The activity of 8-OHdG was calculated according to (Nadja et al. 2001).

Determination of Cytochrome-C Rat ELISA Kit. Determination of Cytochrome-C Rat ELISA Kit was measured According to Abcam's Cytochrome $\mathrm{C}$ kit designed for the quantitative measurement of Cytochrome $\mathrm{C}$ protein rat tissues.

Determination of Bax (Apoptosis regulator Bax) ELISA Kit. Biosource kit is designed for the quantitative measurement of Bax in tissues according to the manufacturer's instructions and guidelines.

\section{Statistical analysis}

The data were subjected to statistical analysis using SPSS program version 20. Independent t-test was adopted to compare between two groups. The values were expressed as mean \pm S.E. and were considered significantly different if $P$ values were $<0.05$ (Bailey, 1995).

\section{Results and Discussion}

Effect of acrylamide on oxidative stress parameters:

The data obtained from Table (1) revealed that the effect of $20 \mathrm{mg} / \mathrm{kg}$ ACR and group received $20 \mathrm{mg}$ ACR with $25 \mathrm{mg} / \mathrm{kg}$ RU on liver, indicated that 8hydroxydeoxy guanidine $(8-\mathrm{OHdG})$, protein carbonyl (PC), lipid peroxidation (LPO), reactive oxygen species (ROS) were increased along with decreased in glutathione peroxidase (GPx) compare to control. On the other hand groups treated with $20 \mathrm{mg}$ ACR plus 100 or $50 \mathrm{mg}$ RU showed nonsignificant effect compare with control. Our result is similar to the results of Harborne and Williams (2000) showed numerous biological activities of interest, for example, antioxidant capacity, antiinflammatory action and stimulation of the immune system. Complementary studies of cytotoxicity, genotoxicity and mutagenicity indicated that the majority of flavonoids (such as catechins, genistein, daizein and rutin, among others) show negative results in these tests (Hollman and Katan, 1996; Nijveldt et al., 2001; Birt et al., 2001; Yao et al., 2004) Ghorbel et al. (2015) showed that acrylamide $(20 \mathrm{mg} / \mathrm{kg}$ body weight for 3 weeks increase malondialdehyde, advanced oxidation protein product, $\mathrm{H}_{2} \mathrm{O}_{2}$ and decrease in GSH and Non-protein thiol levels in erythrocytes. In addition, activities of catalase, glutathione peroxidase and superoxide dismutase were decreased in all treated rats.

The enzymatic antioxidant defense systems are the natural protectors against lipid peroxidation, Glutathione peroxidase, (GPx) is an important scavenger of $\mathrm{H}_{2} \mathrm{O}_{2}$ and prevents the generation of hydroxyl radical and protect the cellular constituents from oxidative damage (Scott et $\boldsymbol{a l}$., 1991) Tables (1).

\section{Effect of acrylamide (ACR) on inflammatory} marker parameters:

The results in Table (2) showed that inflammation marker revealed that the effect of ACR on liver rats. Groups which received $20 \mathrm{mg}$ $/ \mathrm{kg}$ ACR alone showed increase in tumor necrosis factor- $\alpha$ (TNF- $\alpha)$, Nitric Oxide (NO) and myeloperoxidase (MPO) compare with other groups. Our results revealed that MPO was increased significantly due to ACR toxicity, which are in agreement with the findings of Alturfan $\boldsymbol{e t}$ al. (2012). Nakazato et al. (2007) demonstrated that MPO derived chlorinated oxidants and hydroxyl radicals play key roles in inducing oxidative stress mediated apoptosis in myeloid leukemia cells, with ROS being responsible for triggering apoptosis. After exposure to ACR, hepatic pro-inflammatory cytokines expression including tumor necrosis factor- $\alpha$, interleukin-6, interleukin- $1 \beta$ was increased suggesting leucocytes infiltration in the liver. A random DNA degradation was observed on agarose gel only in the liver of exposed rats to acrylamide treatment (Ghorbel et al., 2015). On the other hand the groups which received $20 \mathrm{mg} / \mathrm{kg}$ ACR with 100 or $50 \mathrm{mg} / \mathrm{kg}$ RU represent non-significant effects compare with control group. Jyh-Ming-Chow et al. (2005) evaluated the cytotoxic potential of rutin in RAW264.7 cells (mouse bone marrow cell line) utilizing the MTT assay. After $12 \mathrm{~h}$ of treatment, rutin at concentrations of 25,50 , and $100 \mathrm{mM}$ did not have any toxic effect in this cell line. The lack of cytotoxic effect was also observed by Iffert $\boldsymbol{e t}$ al. (2000) utilizing the MTT assay in three different breast cancer cell lines (MaTu p19, MaTu 0.1 and MaTu 0.25), after $24 \mathrm{~h}$ of exposure to $94.8 \mathrm{mM}$ rutin. These authors recommended eating foods with the flavonoid rutin, since it does not have any harmful effect on health, while protecting tissues against free radicals.

Complementary studies in vivo showed that mice treated by gavage with 625,1250 and $2500 \mathrm{mg} / \mathrm{kg}$ rutin for two consecutive days did not cause primary damage in DNA and or the formation of micronuclei in bone marrow cells (Silva et al., 2002) In the evaluation of the protective effect of rutin in MNCtB assay against the DNA damageinducing agent benzo[a]pyrene only the three highest concentrations, 90, 270 and $810 \mathrm{mM}$ produced statistically significant protection, where the percent reduction in damage was $36 . \%, 51.4 \%$ and $54 . \%$, respectively.

Effect of acrylamide (ACR) on apoptosis marker parameters:

The data obtained from Table (3) revealed that the effect of RU by three doses (100, 50 and $25 \mathrm{mg} / \mathrm{kg}$ ) in caspase-3, Bax, P53 and cytochrome-C on rats treated with ACR after 30 days. The rats which received $20 \mathrm{mg} / \mathrm{kg}$ ACR with 100 and $50 \mathrm{mg} / \mathrm{kg}$ RU represent non-significant compare with control group. On the other hand, groups which received 
$20 \mathrm{mg} / \mathrm{kg}$ ACR alone indicated increased in Caspase-3, Bax, P53 and Cytochrome-C compare with control group. These results according to Hyun-Jung et al. (2000), there two categories of possible mechanisms involved in the protection of hepatic cells (HepG2, HTC) against DNA damage by $\mathrm{B}[\mathrm{a}] \mathrm{P}: 1)$ inactivation of the biotransformation enzymes of the cytochrome P450 system (phase I) which leads to the reduced formation of reactive metabolites and DNA adducts; 2) direct interaction with the derivatives of polycyclic aromatic hydrocarbons. However, further studies are needed to determine the mechanism of action for the protective effect of flavonoids.

Acrylamide produces genotoxic effect through its reactive metabolite, glycidamide, generated by catalysis with cytochrome P450 (Sumner et al, 1999). The resulting metabolite is an epoxide derivate i.e glycidamide which is more reactive toward DNA and proteins than the parent compound, acrylamide (Besartinia and Pfeifer, 2007).
Glycidamide is regarded as a cancer initiating species reacting with DNA to cause mutagenicity and clastogenic (Adler et al, 2000). The clastogenic potential is responsible for dominant lethality targeting male gonadal spermatocytes to result in reproductive toxicity in rodent (Xiao and Tates, 1994; Adler et al, 2000). Several authors reported that ACR has the ability to induce biochemical changes and hormone disturbances (Park et al., 2002; Yousef and El- Demerdash, 2006; Parzefall, 2008).

The experimental data shown in Table (3) no significant effect Caspase-3, Bax, P53 and Cytochrome-C content in concentrated (100, 50 $\mathrm{mg} / \mathrm{kg}$ ) RU with $20 \mathrm{mg} / \mathrm{kg}$ ACR compared with control groups. On the other hand, rats treated with ACR $20 \mathrm{mg} / \mathrm{kg}$ alone indicated a highly significant increase in Caspase-3, Bax, P53 and Cytochrome-C levels in rats compare with control.

Conclusion

The present study declares that, rutin has an appreciable ability to prevent hepatotoxicity caused by acrylamide, possibly via its chemical constituents which has a free radical scavenging properties.

Table (1): Ameliorative effects of quercetin against acrylamide-induced oxidative stress in rat liver

\begin{tabular}{|l|c|c|c|c|}
\hline \multirow{2}{*}{ Groups } & \multicolumn{3}{|c|}{ Oxidative stress in liver } \\
\cline { 2 - 5 } & $\begin{array}{c}\text { GPx } \\
(\text { IU/g protein) }\end{array}$ & $\begin{array}{c}\text { ROS } \\
(\mu \mathrm{mol} \mathrm{NBT/g} \text { tissue) }\end{array}$ & $\begin{array}{c}\text { PC } \\
(\mathbf{n m o l} / \mathbf{m g})\end{array}$ & $\begin{array}{c}\mathbf{8 - O H d G} \\
(\mathbf{n g} / \mathbf{m g} \text { protein) }\end{array}$ \\
\hline Control & $25.63 \pm 0.59^{\mathrm{a}}$ & $19.20 \pm 0.18^{\mathrm{a}}$ & $28.0 \pm 0.58^{\mathrm{a}}$ & $4.61 \pm 0.21^{\mathrm{a}}$ \\
\hline $20 \mathrm{mg}(\mathrm{ACR})$ & $16.83 \pm 0.45^{\mathrm{c}}$ & $23.36 \pm 0.59^{\mathrm{c}}$ & $39.7 \pm 0.81^{\mathrm{c}}$ & $8.51 \pm 0.39^{\mathrm{c}}$ \\
\hline $20 \mathrm{mg} \mathrm{ACR}+100 \mathrm{mg} \mathrm{RU}$ & $25.83 \pm 0.15^{\mathrm{a}}$ & $19.00 \pm 0.68^{\mathrm{a}}$ & $28.6 \pm 0.32^{\mathrm{a}}$ & $4.14 \pm 0.58^{\mathrm{a}}$ \\
\hline $20 \mathrm{mg} \mathrm{ACR}+50 \mathrm{mg} \mathrm{RU}$ & $25.10 \pm 0.41^{\mathrm{a}}$ & $19.13 \pm 0.55^{\mathrm{a}}$ & $28.8 \pm 0.21^{\mathrm{a}}$ & $4.66 \pm 0.63^{\mathrm{a}}$ \\
\hline $20 \mathrm{mg} \mathrm{ACR}+25 \mathrm{mg} \mathrm{RU}$ & $20.31 \pm 1.04^{\mathrm{b}}$ & $19.89 \pm 0.61^{\mathrm{b}}$ & $32.4 \pm 0.80^{\mathrm{b}}$ & $4.81 \pm 0.53^{\mathrm{b}}$ \\
\hline $100 \mathrm{mg} \mathrm{RU}$ alone & $26.17 \pm 0.47^{\mathrm{a}}$ & $18.86 \pm 0.38^{\mathrm{a}}$ & $27.8 \pm 0.60^{\mathrm{a}}$ & $4.18 \pm 0.62^{\mathrm{a}}$ \\
\hline
\end{tabular}

Values are mean $\pm \mathrm{SE}$ of 6 rats. Values with the same letters are not significant at $(\mathrm{P} \leq 0.05) . \mathrm{AA}=$ acrylamide, $\mathrm{RU}=\mathrm{Rutin}$. Values on the same column not sharing the same superscript letters were significantly different $(\mathrm{P}<0.05)$. 
Table (2): Ameliorative effects of quercetin against acrylamide-induced Inflammation markers in liver

\begin{tabular}{|l|c|c|c|}
\hline \multirow{2}{*}{ Groups } & \multicolumn{2}{|c|}{ Inflammation markers in liver } \\
\cline { 2 - 4 } & $\begin{array}{c}\text { MPO } \\
\text { (U/mg protein) }\end{array}$ & $\begin{array}{c}\text { Nitric Oxide } \\
(\mu \mathrm{mol} / \mathrm{mg} \text { protein) }\end{array}$ & $\begin{array}{c}\text { TNF- } \boldsymbol{\alpha} \\
(\mathbf{p g} / \mathbf{m g} \text { protein) }\end{array}$ \\
\hline Control & $10.55 \pm 0.21^{\mathrm{a}}$ & $8.90 \pm 0.53^{\mathrm{a}}$ & $14.21 \pm 0.46^{\mathrm{a}}$ \\
\hline $20 \mathrm{mg}(\mathrm{ACR})$ & $23.38 \pm 0.57^{\mathrm{c}}$ & $13.58 \pm 0.90^{\mathrm{c}}$ & $37.18 \pm 0.98^{\mathrm{c}}$ \\
\hline $20 \mathrm{mg} \mathrm{ACR}+100 \mathrm{mg} \mathrm{RU}$ & $10.58 \pm 0.39^{\mathrm{a}}$ & $8.66 \pm 0.71^{\mathrm{a}}$ & $13.94 \pm 0.65^{\mathrm{a}}$ \\
\hline $20 \mathrm{mg} \mathrm{ACR}+50 \mathrm{mg} \mathrm{RU}$ & $10.96 \pm 0.62^{\mathrm{a}}$ & $8.81 \pm 0.68^{\mathrm{a}}$ & $14.03 \pm 0.48^{\mathrm{a}}$ \\
\hline $20 \mathrm{mg} \mathrm{ACR}+25 \mathrm{mg} \mathrm{RU}$ & $12.71 \pm 0.54^{\mathrm{b}}$ & $10.37 \pm 0.59^{\mathrm{b}}$ & $22.5 \pm 0.21^{\mathrm{b}}$ \\
\hline $100 \mathrm{mg} \mathrm{RU}$ alone & $10.42 \pm 0.32^{\mathrm{a}}$ & $8.59 \pm 0.61^{\mathrm{a}}$ & $13.98 \pm 0.37^{\mathrm{a}}$ \\
\hline
\end{tabular}

Values are mean $\pm \mathrm{SE}$ of 6 rats. Values with the same letters are not significant at $(\mathrm{P} \leq 0.05) . \mathrm{AA}=$ acrylamide, $\mathrm{RU}=\mathrm{Rutin}$. Values on the same column not sharing the same superscript letters were significantly different $(P<0.05)$.

Table (3): Ameliorative effects of quercetin against acrylamide-induced apoptosis markers in liver

\begin{tabular}{|l|c|c|c|c|}
\hline \multirow{2}{*}{ Groups } & \multicolumn{3}{|c|}{ Apoptosis marker in liver } \\
\cline { 2 - 5 } & $\begin{array}{c}\text { Caspase-3 } \\
(\mathbf{n g} / \mathbf{m g} \text { protein) }\end{array}$ & $\begin{array}{c}\text { Bax } \\
(\mathbf{n g} / \mathbf{m g} \text { protein) }\end{array}$ & $\begin{array}{c}\text { P53 } \\
(\mathbf{p g} / \mathbf{m l})\end{array}$ & $\begin{array}{c}\text { Cytochrome-C } \\
(\mathbf{n g} / \mathbf{m l})\end{array}$ \\
\hline Control & $0.93 \pm 0.10^{\mathrm{a}}$ & $0.23 \pm 0.06^{\mathrm{a}}$ & $74.21 \pm 11.95^{\mathrm{a}}$ & $0.46 \pm 0.22^{\mathrm{a}}$ \\
\hline $20 \mathrm{mg} \mathrm{(ACR)}$ & $2.17 \pm 0.15^{\mathrm{c}}$ & $1.38 \pm 0.12^{\mathrm{c}}$ & $182.21 \pm 8.39^{\mathrm{c}}$ & $0.91 \pm 0.32^{\mathrm{c}}$ \\
\hline $20 \mathrm{mg} \mathrm{ACR}+100 \mathrm{mg}$ RU & $0.94 \pm 0.18^{\mathrm{a}}$ & $0.24 \pm 0.09^{\mathrm{a}}$ & $76.00 \pm 21.16^{\mathrm{a}}$ & $0.46 \pm 0.51^{\mathrm{a}}$ \\
\hline $20 \mathrm{mg} \mathrm{ACR}+50 \mathrm{mg} \mathrm{RU}$ & $0.95 \pm 0.08^{\mathrm{a}}$ & $0.25 \pm 0.16^{\mathrm{a}}$ & $76.26 \pm 16.07^{\mathrm{a}}$ & $0.48 \pm 0.24^{\mathrm{a}}$ \\
\hline $20 \mathrm{mg} \mathrm{ACR}+25 \mathrm{mg} \mathrm{RU}$ & $1.52 \pm 0.17^{\mathrm{b}}$ & $0.64 \pm 0.05^{\mathrm{b}}$ & $119.60 \pm 16.03^{\mathrm{b}}$ & $0.68 \pm 0.31^{\mathrm{b}}$ \\
\hline $100 \mathrm{mg} \mathrm{RU} \mathrm{alone}$ & $0.91 \pm 0.13^{\mathrm{a}}$ & $0.21 \pm 0.03^{\mathrm{a}}$ & $72.21 \pm 7.84^{\mathrm{a}}$ & $0.42 \pm 0.08^{\mathrm{a}}$ \\
\hline
\end{tabular}

Values are mean $\pm \mathrm{SE}$ of 6 rats. Values with the same letters are not significant at $(\mathrm{P} \leq 0.05)$. $\mathrm{AA}=$ acrylamide, $\mathrm{RU}=\mathrm{Rutin}$. Values on the same column not sharing the same superscript letters were significantly different $(\mathrm{P}<0.05)$.

\section{Histopathological findings of liver}

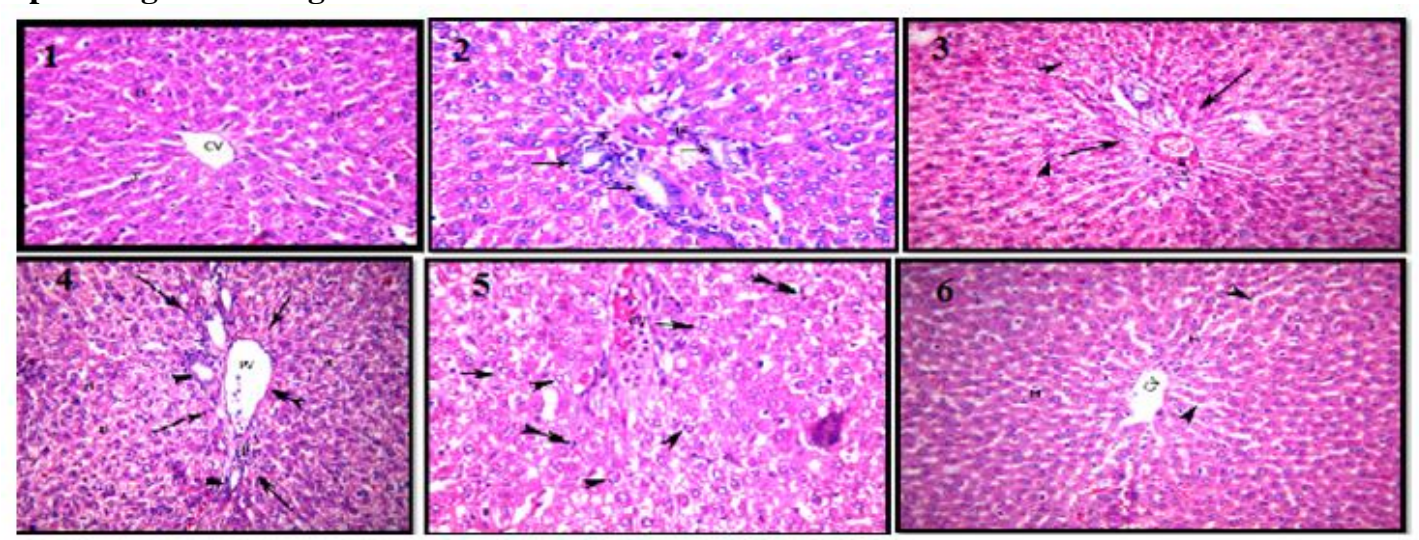

Fig (1): Photomicrograph of liver section taken from control animals showing normal architecture with normal appearance of hepatocytes $(\mathrm{H})$, sinusoid (S) and vascular channels as central vein (CV). Fig (2): Photomicrograph of liver section taken from animals treated 20 mg acrylamide alone showing most portal area were constricted with proliferated bile duct (arrow) and periportal inflammation (IF). Proliferated van kupfer cells also were seen. Fig (3): A photomicrograph of liver section taken from animals treated $20 \mathrm{mg}$ acrylamide with $100 \mathrm{mg}$ Rutin showing constricted portal area (arrow) with mild vacuolated hepatocytes (head of arrow) and mild aggregation of inflammatory cells (IF).Fig (4):A photomicrograph of liver section taken from animals treated $20 \mathrm{mg}$ acrylamide with $50 \mathrm{mg}$ rutin showing expanded portal area (arrow), mild dilated congested portal vein (PV) and proliferated bile duct (head of arrow) together with moderate vacuolated hepatocytes (H). Mild inflammatory cells infiltrations in periportal were also seen (IF). Fig (5): A photomicrograph of liver section taken from animals treated $20 \mathrm{mg}$ acrylamide with $25 \mathrm{mg}$ rutin showing sever vacuolated hepatocytes (arrow) with magnetite chromatin (head of arrow). Proliferated vankuffer cells ( 2 head of arrow) and dilated congested central vein (CV) were also seen.

Fig (6): A photomicrograph of liver section taken from animals' treated $100 \mathrm{mg}$ rutin alone showing normal hepatocytes $(\mathrm{H})$, central vein (CV) and sinusoidal (head of arrow). 
References

- Adler ID, Baumgartner A, Gonda H, Friedman MA And Skerhut, M (2000) 1-Aminobenzotriazole inhibits acrylamide induced dominant lethal effects in spermatids of male mice. Mutagen. 15 (2), 133-136

- Alturfan AA, Tozan-Beceren A, Sehirli AO, Demiralp E and Sener $G$ (2012) Resveratrol ameliorates oxidative DNA damage and protects against acrylamide-induced oxidative stress in rats. Mol Biol Rep (39), 4589-4596

- American Institute of Nutrition (1980) Report of the American Institute of Nutrition. Ad Hoc Committee J Nutrition. (110), 13401348

- Bailey NTJ (1995). Statistical methods in biology. 3rd ed.,Cambridge University Press, UK.El-sheikh, N.M.32

- Banchroft D, Stevens A and Turner D R (1996) Theory and practice of histological techniques. Fourth Ed. Churchil Livingstone, New York, London, San Francisco, Tokyo., (92), $122-128$.

- Besaratinia A, and Pfeifer GP (2007) A review of mechanisms of acrylamide carcinogenicity. Carcinogenesis (28), 519-528

- Birt DF, Hendrich P, Weiqun W (2001). Dietary agents in cancer prevention: flavonoids and isoflavonoids. Plant Foods Hum Nut:48:112-120

- Blasc, AJ, Gonzalez MC, Escarpa A (2004). Electrochemical approach for dis-criminating and measuring predominant flavonoids and phenolic acids using differential pulse voltammetry: towards an electrochemical index of natural antioxidants. Analytica Chimica Acta 511, 71-81

- Bonavida, B (1991) Immunomodulatory effect of tumor necrosis factor. Biotherapy, (3), 127-133.

- Bradley, P.P., Christensen, R.D. and Rothstein, G. (1982) Cellular and extracellular myeloperoxidase in pyogenic inflammation. Blood, (60), 618-622

- Brigelius-Flohe $R$ (1999) Tissue-specific functions of individual glutathione peroxidases. Free RadicBiol Med. 27(9-10), 951-65.

- Camacho L, Latendresse JR, Muskhelishvili L, Patton R, Bowyer JF, Thomas $M$ and Doerge DR (2012) Effects of acrylamide exposure on serum hormones, gene expression, cell proliferation, and histopathology in male reproductive tissues of Fischer 344 rats. Toxicology Letters, (211), 135-143

- Forstova B, Belkova K, Riddellova L, Vaclavik J, Prihoda and Hajslova J (2014) Food Control, (38), 221-226.

- Ghorbel I, Maktouf S, Kallel C, Chaabouni S E, Boudawara T and Zeghal N (2015) Disruption of erythrocyte antioxidant defense system, hematological parameters, induction of proinflammatory cytokines and DNA damage in liver of coexposed rats to aluminium and acrylamide. Chemico-biological interactions, (236), 31-40

- Ghorbel I, Maktouf S, Kallel C, Chaabouni S E, Boudawara T and Zeghal N (2015) Disruption of erythrocyte antioxidant defense system, hematological parameters, induction of proinflammatory cytokines and DNA damage in liver of coexposed rats to aluminium and acrylamide. Chemico-biological interactions, (236), 31-40

- Harborne JB and Williams CA (2000). Advances in flavonoid research since 1992. Phytochemistry 55:481-504

- Hasumura M, Yasuhara K, Tamura T, Imai T, Mitsumori K, Hirose M (2004). Evaluation of the toxicity of enzymatically decomposed rutin with 13-weeks dietary administration to Wistar rats. Food and Chemical Toxicology 42, 439-444

- Hollman PCH and Katan MB (1996). Analysis and health effects of flavonoids. Food Chem; 57:43-6

- Hyun-Jung K, Hyang-Sook C, Yang R (2000). Inhibition of benzo[a]pyrene-induced cytotoxicity and cytochrome P4501A activity by dietary flavonoids in human liver cell model: structureactivity relationship. Biotech Lett;22:1941-6

- Iffert T, Soldan M, Moeller A, Maser E (2000). Modulation of daunorubicin toxicity by liposomal encapsulation and use of specific inhibitors in vitro. Toxicology; 144:189-95

- Jyh-Ming-Chow SC, Shen SK, Huan HY, Lin YC, Chen O (2005). Quercetin but not rutin and quercitrin, prevention of $\mathrm{H} 2 \mathrm{O} 2-$ induced apoptosis via anti-oxidant. Biochem Pharm;6:1839-51

- Levine R L, Garland D, Oliver C N, Amici A, Climent I, Lenz A G, Ahn B W, Shaltiel S and Stadtman E $R$ (1990) Determination of carbonyl content in oxidatively modified proteins. Methods Enzymol. (186), 464-478
- Liu Y, Tian X, Gou L, Fu X, Li S, Lan N (2012) Protective effect of L-citrulline against ethanol-induced gastric ulcer in rats. Environ Toxicol Pharmacol. (34),280-287

- Lowry OH, Roseborough NJ, Farr AL and Randall RL (1951) Protein measurement with phenol reagent. Journal of Biological Chemistry. 193 (1), 265-275

- Mottram D S, Wedzicna B L And Dodson A T (2002) Acrylamide is formed into maillard reaction. Nature, (419), 448-449 - Nadja C, de Souza-Pinto, Lars Eide, Barbara A, Hogue Tanja Thybo, Tinna Stevnsner, Erling Seeberg Arne, Klungland and Vilhelm A, Bohr July (2001). Rat 8-hydroxy-2deoxyguanosine (8-OHdG) ELISA Kit

- Nakazato T, Sagawa M, Yamato K, Xian M, Yamamoto T, Suematsu M, Ikeda Y, Kizaki M (2007) Myeloperoxidase is a key regulator of oxidative stress mediated apoptosis in myeloid leukemic cells. Clin. Cancer Res, (13), 5436-5445.

- Nijveldt RJ, Nood EV, DECV Hoorn, Boelens PG, Norren KV (2001). Flavonoids: a review of probable mechanisms of action and potential applications. Am J Clin Nutr;4:418-25.

- Park Jougjoa, Lisa M, Kamendulis Marvin A and Friedman (2002) Acrylamide-Induced Cellur Transformation." Toxicological Sciences (65), 177-183.

- Parzefall (2008) Mini review on the toxicity of dietary acrylamide,"Food and Chemical Toxicology, vol. 46, no. 4, pp. 1360-1364.

- Scott TR, Rowland SM, Rodgers RS and Bodine AB (1991) Genetic selection for aflatoxin B1 resistance influences chicken T-cell and thymocyte proliferation. Devel Comp Immunol (15), 383-391

- Silva J, Hermann SM, Heuser W, Marroni N, Gonza' lezGallego J, Erdtmann B (2002). Evaluation of the genotoxic effect of rutin and quercetin by comet assay and micronucleus test. Food Chem Toxicol; 40:941-7.

- Smith B (1991) Fibroadenomas. In: Breast Diseases. Harris, JR; Hellman, S: Henderson, IC; et al., eds. JP Lippincott Company: Philadelphia. Pp 34-37

- Sumner SC, Fennell TR, Moore TA, Chanas B, Gonzalez F and Ghanayem BI (1999) Role of cytochrome P450 2E1 in the metabolism of acrylamide and acrylonitrile in mice. Chemical Reseach in Toxicology, (12), 1110-1116.

- Uchiyama M and Mihara M (1978) Determination of malonaldehyde precursor in tissue by thiobarbituric acid test. Anal. Biochem ., (86), 271 - 278.

- Undeger U, Aydin, S, Bas, aran, AA, Bas aran N, (2004). The modulating effects of quercetin and rutin on the mitomycin $\mathrm{C}$ induced DNA damage. Toxicology Letters 151, 143-149

- Vrablic AS, Albright CD, Craciunescu CN, Salanik RI and Zesel SH (2001) Altered mitochondrial function and over generation of reactive oxygen species precede the induction of apoptosis by 1-O-octadecyl-2-methyl-racglycero-3-phosphocholine in p53-defective hepatocytes Federation of Americon Societies for ExperimentalBiology journal, (15), 1739-1744

- Wadworth AN and Faulds D (1992) Hydroxyethylrutosides. A review of its pharma-cology, and therapeutic efficacy in venous insufficiency and related disorders. Drugs 44, 1013-1032.

- Wang CC, Huang YJ, Chen LG, Lee LT and Wang LL (2002) Inducible nitric oxide synthase inhibitors of Chinese herbs III. Rheum palmaturn. Planta Medica 68 (10), 869-874

- Xiao Y and Tates AD (1994) Increased frequencies of micronuclei in early spermatids of rats following exposure of young primary spermatocytes to acrylamide. Mutation Research, (309), 245- 253

- Yao LH, Jiang YM, Shi J, Toma' s-Barberan FA, Datta N, Singanusong R(2004). Flavonoids in food and their health benefits. Plant Foods Hum Nutr;59:113-22

- Yousef M I and El- Demerdash F M (2006) Acrylamideinduced oxidative stress and biochemical perturbations in rats Toxicol., (219), $133-141$ 